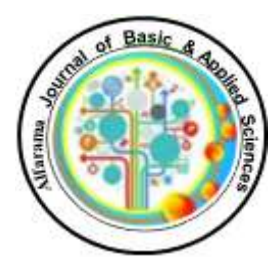

ISSN 2682-275X
Alfarama Journal of Basic \& Applied Sciences

Faculty of Science Port Said University

July 2021, Volume 2, Issue 2 https://ajbas.journals.ekb.eg

ajbas@ @ci.psu.edu.eg

http://sci.psu.edu.eg/en/

Submitted: $30 / 12 / 2020$

Accepted: 07 / $02 / 2021$

Pages: 307-315

\title{
Rapidly Solidified Pb-Sn-Ca-Ag Alloy for Electrowinning Anode
}

\author{
M. Kamal ${ }^{1}$, R. M. Shalaby ${ }^{1}$, T. El Ashram², S. M. Abdelaty ${ }^{2}$, A. Hany ${ }^{2, *}$ \\ ${ }^{1}$ Physics Department, Faculty of Science, Mansoura University, Mansoura, Egypt \\ ${ }^{2}$ Physics Department, Faculty of Science, Port-Said University, Port-Said, Egypt \\ * Corresponding author: amaalamreya@yahoo.com
}

\begin{abstract}
Electrowinning of metals from aqueous solutions has been used for over a century. It is the main recovery method for zinc, gold, silver, copper and cobalt. Lead alloys for anode are widely used because their desirable characteristics like low cost, reducing of power consumption and longer life time. So that the aim of the present work is to study the effect of addition of $\mathrm{Ag}$ and rapid solidification using melt spinning technique on the structure, physical and electrochemical properties of $\mathrm{Pb}-\mathrm{Sn}-\mathrm{Ca}$ alloys to be used as anode for electrowinning cell. Six rapidly solidified alloys of Pb-10Sn-2.5Ca-xAg (x = $0,0.5,1,1.5,2,2.5 \mathrm{wt} . \%)$ were produced by melt-spinning technique. X-ray diffraction analysis and differential scanning calorimetry have been carried out. Also, mechanical, electrical and electrochemical properties were measured. Here we show that adding of $\mathrm{Ag}$ to $\mathrm{Pb}-10 \mathrm{Sn}-2.5 \mathrm{Ca}$ improves its mechanical properties. This is shown in the increase of Young's modulus and micro creep behavior as well as enhancement of corrosion resistance and electrical conductivity. Among the prepared rapidly solidified alloys, the $\mathrm{Pb}-10 \mathrm{Sn}-2.5 \mathrm{Ca}-1.5 \mathrm{Ag}$ in wt.\% is considered as the one with the best composition to be used as anode for electrowinning cell.
\end{abstract}

Keywords:

Melt spinning technique, mechanical properties, micro creep, electrical properties, lead alloys, electrowinning.

\section{INTRODUCTION}

The electrowinning of metals from aqueous solutions has used for over a century. The enhancement of the life time of electrowinning cell depends on the anode material. The important properties of anode alloys for electrowinning cell are good electrical conductivity, high mechanical strength, corrosion resistance and the compatibility with the active materials. Lead based anodes are characterized by good conductivity and high potential, so it is used in the electrowinning of nonferrous metal as copper and zinc [1]. $\mathrm{Pb}$ anodes are characterized by 
high mechanical strength, so it will not be damaged or deformed during the use [2]. Because of pure lead anode creep, lead must be alloyed with some elements such as $\mathrm{Ag}, \mathrm{Co}, \mathrm{Sb}, \mathrm{Ca}$, $\mathrm{Bi}$ and $\mathrm{Sr}[3]$.

To minimize cathode contamination, the anode surface must be corrosion resistant before placing of anode in electrowinning process [4]. In cast $\mathrm{Pb}-\mathrm{Ca}-\mathrm{Sn}$ alloys, the calcium content produces large grains with minimal alloy segregation and the calcium content is 0.03 0.08 wt.\% to inhibit the formation of $\mathrm{Pb}_{3} \mathrm{Ca}$ particles, which cause non uniform corrosion. Also, the addition of calcium enhances the mechanical and electrical properties [5-6]. Tin content in $\mathrm{Pb}-7 \mathrm{Sn}$ anode for chromium plating vary from $6 \mathrm{wt} . \%$ to $10 \mathrm{wt} . \%$ because the high tin content increase corrosion resistance [7]. $\mathrm{Pb}-\mathrm{Ca}-\mathrm{Sn}-\mathrm{Co}$ alloy reduce the use of cobalt in the copper electrolyte to enhance oxygen evolution at the anode [8]. Therefore, the aim of the present work to reveal the effect silver on the structure and properties of $\mathrm{Pb}-\mathrm{Sn}-\mathrm{Ca}$ alloys which are used for anode of electrowinning application.

\section{EXPERIMENTAL}

Six alloys of compositions $\mathrm{Pb}-10 \mathrm{Sn}-2.5 \mathrm{Ca}-\mathrm{xAg}(\mathrm{x}=0,0.5,1,1.5,2,2.5 \mathrm{wt} . \%)$ were produced by a single copper roller melt-spinning technique ( shown in Figure 1). The materials used were from the international company for scientific and medical supplies. The starting purity was better than $99.9 \%$. The quantities of these metals were weighted out (10 $\mathrm{g}$ for each composition) and melted in a porcelain crucible and the casting was done in air at $700{ }^{\circ} \mathrm{C}$. The produced ribbons are shown in Figure 2. The speed of the copper wheel was fixed at $2900 \mathrm{rpm}$, which corresponds to a linear speed of $30.4 \mathrm{~ms}^{-1}$. X-ray diffraction (XRD) analysis was carried out with a Shimadzu X-ray diffractometer (DX-30), using $\mathrm{Cu} \mathrm{K} \alpha$ radiation with Ni filter $(\lambda=0.154056 \mathrm{~nm})$. Differential scanning calorimetry (Shimadzu DSC- 50) was applied with heating rate $10 \mathrm{~K} / \mathrm{min}$ and the melting temperatures of the produced alloys were calculated. BS407 wide range precision micro- ohmmeter was used to measure the electrical resistivity. A digital Vickers microhardness tester Model-FM-7 was used to measure Vickers microhardness number HV and microcreep as developed and confirmed by T. El Ashram [910]. In this method the fractional increase in the area of indentation is considered to be the strain. It was found that this strain increases by increasing the indentation time from which microcreep behavior can be determined. The potentiodynamic current-potential curves were recorded by changing the electrode potential automatically from -500 to $500 \mathrm{mV}$ in case of Csteel with scanning rate $5 \mathrm{mVs}^{-1}$ by using computer controlled potentiostate Gamry PCI4-G750 with DC 105 software for calculations and storted the data.

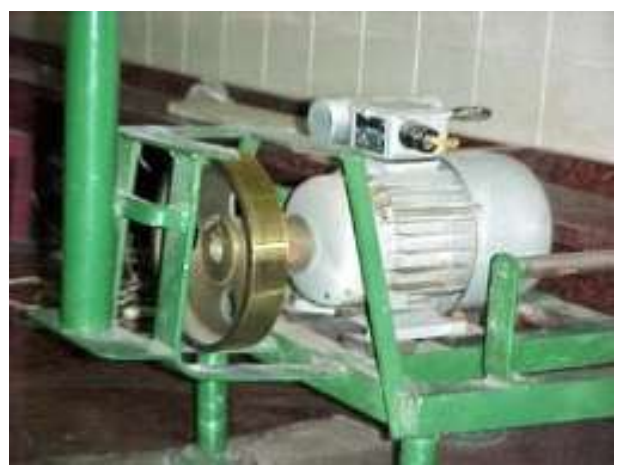

Figure 1. Melt- spinning technique. 


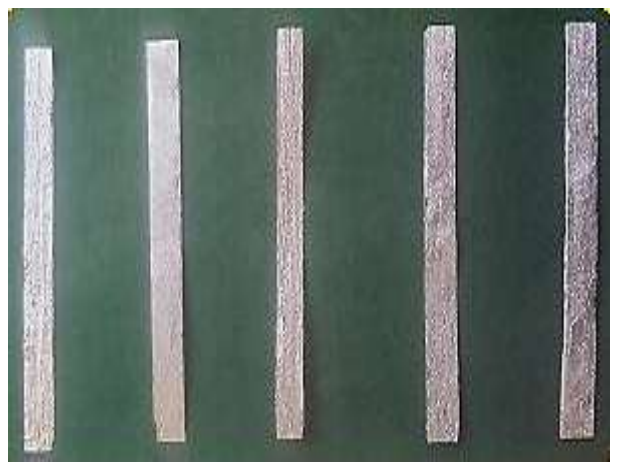

Figure 2. As-quenched melt spun ribbons.

\section{RESULTS AND DISCUSSION}

\subsection{CRYSTAL STRUCTURE}

The phases were identified from ICSD using POWD-12++, (1997) [11] and the PDF card number is shown in Table 1. Figure 3. shows the XRD patterns for as-quenched melt-spun ribbons of compositions $\mathrm{Pb}-10 \mathrm{Sn}-2.5 \mathrm{Ca}-\mathrm{xAg}$ ( $\mathrm{x}=0,0.5,1,1.5,2,2.5 \mathrm{wt} . \%)$. It shows that the eutectic mixture of $\mathrm{Pb}$ and $\mathrm{Sn}$ phases up to the composition $\mathrm{Pb}-10 \mathrm{Sn}-2.5 \mathrm{Ca}-1 \mathrm{Ag}$, in which formation of $\mathrm{Ag}_{3} \mathrm{Sn}$ intermetallic compound was observed in $\mathrm{Pb}-10 \mathrm{Sn}-2.5 \mathrm{Ca}-1 \mathrm{Ag}, \mathrm{Pb}-10 \mathrm{Sn}$ 2.5Ca-1.5Ag and $\mathrm{Pb}-10 \mathrm{Sn}-2.5 \mathrm{Ca}-2 \mathrm{Ag}$ alloys. But $\mathrm{CaPb}_{3}$ and $\mathrm{Ag}_{3} \mathrm{Sn}$ intermetallic compounds were formed in $\mathrm{Pb}-10 \mathrm{Sn}-2.5 \mathrm{Ca}-1 \mathrm{Ag}$ alloy. $\mathrm{Ag}_{3} \mathrm{Sn}$ intermetallic compound has orthorhombic crystal system with space group $\mathrm{Cmcm}$ but $\mathrm{CaPb}_{3}$ intermetallic compound has cubic crystal system with space group $\mathrm{Pm} \overline{3} \mathrm{~m}$. The $\mathrm{Ag}_{3} \mathrm{Sn}$ intermetallic compound is termed HumeRothery electron compound because it is formed at certain valence electron concentration ratio (VECR). The VECR for $\mathrm{Ag}_{3} \mathrm{Sn}$ formation is 7/4. The $\mathrm{CaPb}_{3}$ is classified as electrochemical compound which is formed due to the difference in electronegativity between $\mathrm{Ca}$ and $\mathrm{Pb}$. The variation of lattice parameters and volume of the unit cell of matrix is shown in Table 1. The lattice parameter $\boldsymbol{a}$ of $\mathrm{Pb}$ matrix was calculated from the peak position of highest intensity which corresponding to the plane (111). The lattice parameter $\boldsymbol{a}$ was increased by the addition of Ag from $4.9459 \AA$ for $\mathrm{Pb}-10 \mathrm{Sn}-\mathrm{Pb}-10 \mathrm{Sn}-2.5 \mathrm{Ca}$ to $4.9489 \AA$ for $\mathrm{Pb}-10 \mathrm{Sn}-2.5 \mathrm{Ca}-0.5 \mathrm{Ag}$ alloy and then decreased to $4.9469 \AA$ for $\mathrm{Pb}-10 \mathrm{Sn}-2.5 \mathrm{Ca}-1.5 \mathrm{Ag}$ then increased to $4.9489 \AA$ for Pb-10Sn-2.5Ca-2Ag but finally it decreased to the minimum value, $4.9463 \AA$ for $\mathrm{Pb}-10 \mathrm{Sn}-2.5 \mathrm{Ca}-2.5 \mathrm{Ag}$ alloy. The decrease in $\boldsymbol{a}$ may be due to the dissolving of $\mathrm{Ag}$ atom, which has small radius compared to $\mathrm{Pb}$ atom. The decrease in $\boldsymbol{a}$, which was observed for $\mathrm{Pb}-10 \mathrm{Sn}-2.5 \mathrm{Ca}-1 \mathrm{Ag}$ and $\mathrm{Pb}-10 \mathrm{Sn}-2.5 \mathrm{Ca}-1.5 \mathrm{Ag}$ alloys, may be due to the formation of $\mathrm{Ag}_{3} \mathrm{Sn}$ intermetallic compound in that alloy. The same behavior was observed for the volume of unit cell $v$ of the matrix since $v=a^{3}$. 


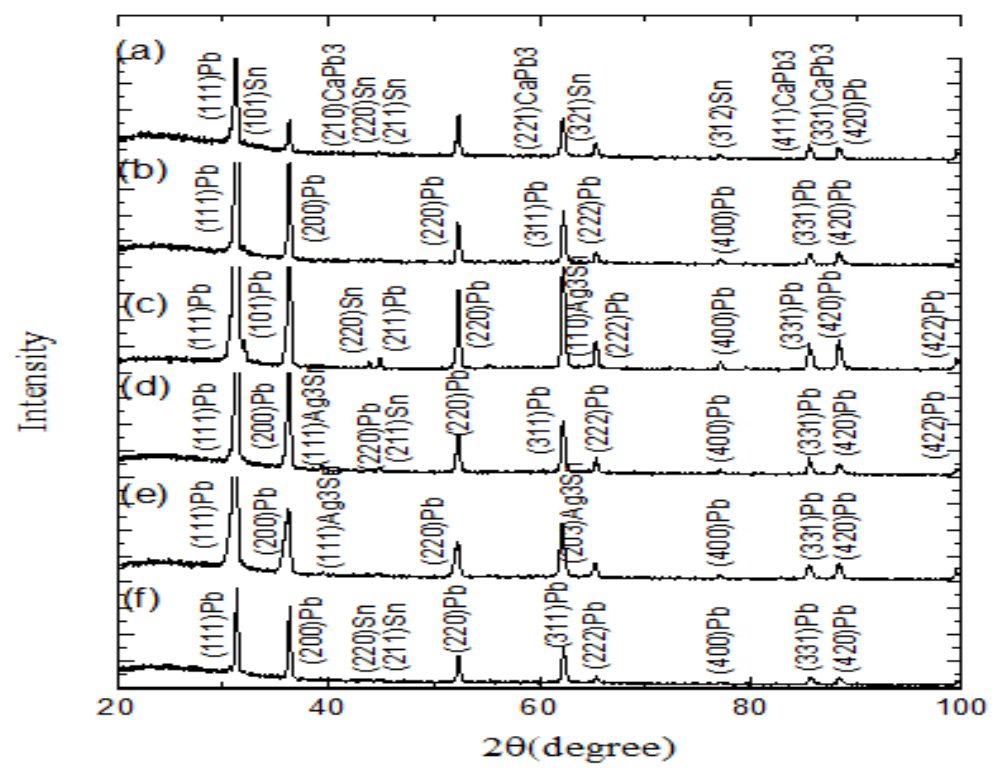

Figure 3. X-ray diffraction pattern of as-quenched melt-spun (a) $\mathrm{Pb}-10 \mathrm{Sn}-2.5 \mathrm{Ca}$, (b) $\mathrm{Pb}$ 10Sn-2.5Ca-0.5Ag, (c) Pb-10Sn-2.5Ca-1Ag, (d) Pb-10Sn-1.5Ag, (e) Pb-10Sn-2.5Ca-2Ag, (f) Pb-10Sn-2.5Ca-2.5Ag alloys.

Table 1. Details of XRD analysis of Pb-10Sn-2.5Ca-XAg (0, 0.5, 1, 1.5, 2, 2.5 wt. \%) alloys.

\begin{tabular}{|c|c|c|c|c|}
\hline Alloys & $\begin{array}{l}\text { Phases } \\
\text { present }\end{array}$ & $\begin{array}{c}\text { Lattice parameter } \\
\text { of the matrix } \mathrm{Pb} \\
\mathrm{a}(\AA)\end{array}$ & $\begin{array}{l}\text { Unit cell } \\
\text { volume } \\
\text { v }(\AA) 3\end{array}$ & Cards no. \\
\hline $\mathrm{Pb}-10 \mathrm{Sn}-2.5 \mathrm{Ca}$ & $\begin{array}{c}\mathrm{Pb} \\
\mathrm{Sn} \\
\mathrm{CaPb}_{3}\end{array}$ & 4.9459 & 120.99 & $\begin{array}{l}01-072-6646 \\
03-065-0296 \\
03-065-8365\end{array}$ \\
\hline Pb-10Sn-2.5Ca-0.5Ag & $\mathrm{Pb}$ & 4.9489 & 121.21 & $01-072-6646$ \\
\hline $\mathrm{Pb}-10 \mathrm{Sn}-2.5 \mathrm{Ca}-1 \mathrm{Ag}$ & $\begin{array}{c}\mathrm{Pb} \\
\mathrm{Sn} \\
\mathrm{CaPb}_{3} \\
\mathrm{Ag}_{3} \mathrm{Sn}\end{array}$ & 4.9476 & 121.11 & $\begin{array}{l}01-072-6646 \\
03-065-0296 \\
03-065-8365 \\
00-056-1242\end{array}$ \\
\hline $\mathrm{Pb}-10 \mathrm{Sn}-2.5 \mathrm{Ca}-1.5 \mathrm{Ag}$ & $\begin{array}{c}\mathrm{Pb} \\
\mathrm{Sn} \\
\mathrm{Ag}_{3} \mathrm{Sn}\end{array}$ & 4.9469 & 121.06 & $\begin{array}{l}01-072-6646 \\
03-065-0296 \\
00-056-1242\end{array}$ \\
\hline $\mathrm{Pb}-10 \mathrm{Sn}-2.5 \mathrm{Ca}-2 \mathrm{Ag}$ & $\begin{array}{c}\mathrm{Pb} \\
\mathrm{Ag} 3 \mathrm{Sn}\end{array}$ & 4.9489 & 121.20 & $\begin{array}{l}01-072-6646 \\
00-056-1242\end{array}$ \\
\hline Pb-10Sn-2.5Ca-2.5Ag & $\begin{array}{l}\mathrm{Pb} \\
\mathrm{Sn}\end{array}$ & 4.9463 & 121.01 & $\begin{array}{l}01-072-6646 \\
03-065-0296\end{array}$ \\
\hline
\end{tabular}




\subsection{THERMAL ANALYSIS}

The DSC curves for the three alloys of Pb-10Sn-2.5Ca, Pb-10Sn2.5Ca-1.5Ag and Pb-10Sn$2.5 \mathrm{Ca}-2.5 \mathrm{Ag}$ are shown in Figure 4 . In the DSC curves, the melting point is typically calculated by first selecting the most steeping part of the low temperature side of well of the heat absorption, obtaining the slope, then extrapolating the slope line to the temperature at the zero differential heat flow axis. The pasty is defined as the temperature difference between solidus and liquidus temperature. It is found that there is no variation in the decomposition behavior for $\mathrm{Pb}-10 \mathrm{Sn}-2.5 \mathrm{Ca}-1.5 \mathrm{Ag}$ and $\mathrm{Pb}-10 \mathrm{Sn}-2.5 \mathrm{Ca}-2.5 \mathrm{Ag}$ alloys, as indicated in Figure 4. The addition of $A g$ decreases the melting temperature $\left(\mathrm{T}_{\mathrm{m}}\right)$ and slightly increases the enthalpy of fusion $\left(\Delta \mathrm{H}_{\mathrm{f}}\right)$ as shown in Table 2 . The melting temperature is the ratio between the enthalpy of fusion and the entropy of fusion. Therefore the decrease in $T_{m}$ may be due to the increase in entropy which resulted from the large defects and phases introduced in the samples due to the addition of $\mathrm{Ag}$.

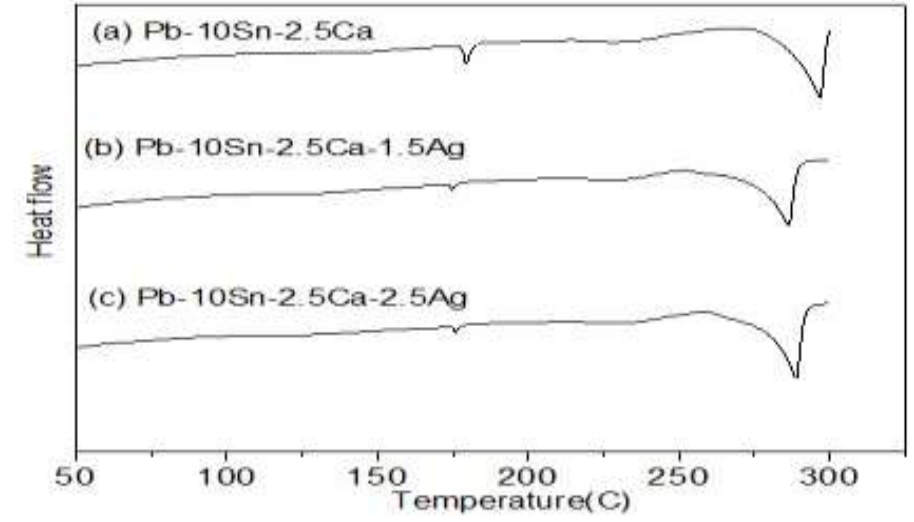

Figure 4. Differential scanning calorimetry (DSC) curves for as-quenched melt- spun $\mathrm{Pb}$ 10Sn-2.5Ca-xAg (x=0, 1.5, 2.5 wt. \%) alloys.

Table 2. Details of DSC analysis of as-quenched melt-spun Pb-10Sn-2.5Ca-xAg ( $x=0,1.5$, 2.5 wt. \%) alloys.

\begin{tabular}{|c|c|c|c|c|c|}
\hline Alloy & $\begin{array}{c}\mathrm{T}_{\mathrm{s}} \\
\left({ }^{\circ} \mathrm{C}\right)\end{array}$ & $\begin{array}{c}\mathrm{T}_{1} \\
\left({ }^{\circ} \mathrm{C}\right)\end{array}$ & $\begin{array}{c}\text { Pasty } \\
\text { Range } \\
\left({ }^{\circ} \mathrm{C}\right)\end{array}$ & $\begin{array}{c}\mathrm{T}_{\mathrm{m}} \\
\left({ }^{\circ} \mathrm{C}\right)\end{array}$ & $\begin{array}{c}\Delta \mathrm{H} \\
\left(\mathrm{Jg}^{-1}\right)\end{array}$ \\
\hline $\mathrm{Pb}-10 \mathrm{Sn}-2.5 \mathrm{Ca}$ & 285.41 & 305.74 & 20.33 & 298.13 & 29.12 \\
\hline $\mathrm{Pb}-10 \mathrm{Sn}-2.5 \mathrm{Ca}-1.5 \mathrm{Ag}$ & 274.59 & 294.19 & 19.60 & 287.60 & 31.73 \\
\hline $\mathrm{Pb}-10$ Sn-2.5Ca-2.5Ag & 278.48 & 297.60 & 19.12 & 290.26 & 32.72 \\
\hline
\end{tabular}

\subsection{MECHANICAL PROPERTIES}

\subsubsection{YOUNG'S MODULUS}

Figure 5. (a) shows the variation of Young's modulus (E) with the variation of $\mathrm{Ag}$ concentration of as-quenched melt-spun Pb-10Sn-2.5Ca-xAg ( $x=0,0.5,1,1.5,2,2.5$ wt.\%) 
alloys. E was decreased by $\mathrm{Ag}$ addition from $39.93 \mathrm{GPa}$ for $\mathrm{Pb}-10 \mathrm{Sn}-2.5 \mathrm{Ca}$ alloy to 20.23 $\mathrm{GPa}$ for $\mathrm{Pb}-10 \mathrm{Sn}-2.5 \mathrm{Ca}-0.5 \mathrm{Ag}$ then, increased to $40.07 \mathrm{GPa}$ for $\mathrm{Pb}-10 \mathrm{Sn}-2.5 \mathrm{Ca}-1 \mathrm{Ag}$ to 50.37 $\mathrm{GPa}$ for $\mathrm{Pb}-10 \mathrm{Sn}-2.5 \mathrm{Ca}-1.5 \mathrm{Ag}$ alloy and decreased to $25.57 \mathrm{GPa}$ for $\mathrm{Pb}-10 \mathrm{Sn}-2.5 \mathrm{Ca}-2 \mathrm{Ag}$ alloy then, it reached to $31.06 \mathrm{GPa}$ for $\mathrm{Pb}-10 \mathrm{Sn}-2.5 \mathrm{Ca}-2.5 \mathrm{Ag}$ alloy. The decrease in $\mathrm{E}$ may be due to dissolving of $\mathrm{Ag}$ atoms in $\mathrm{Pb}$ lattice cause attenuation to the bond strength between $\mathrm{Pb}$ atoms. The increase in $\mathrm{E}$ for $1 \mathrm{wt} . \%$ and $1.5 \mathrm{wt} . \% \mathrm{Ag}$ can be attributed to formation of $\mathrm{CaPb}_{3}$ and $\mathrm{Ag}_{3} \mathrm{Sn}$ intermetallic compounds which are hard phases.

Figure 5. (b) shows the variation of internal friction $\left(Q^{-1}\right)$ with the variation of $\mathrm{Ag}$ concentration. It shows that the value of $\mathrm{Q}^{-1}$ increased with increasing of $\mathrm{Ag}$ addition from 0.018 for $\mathrm{Pb}-10 \mathrm{Sn}-2.5 \mathrm{Ca}$ alloy, reaching the maximum value of 0.189 for $\mathrm{Pb}-10 \mathrm{Sn}-2.5 \mathrm{Ca}-$ $1.5 \mathrm{Ag}$ alloy, then decreased to 0.73 for $\mathrm{Pb}-10 \mathrm{Sn}-2.5 \mathrm{Ca}-2 \mathrm{Ag}$ then to 0.024 for $\mathrm{Pb}-10 \mathrm{Sn} 2.5 \mathrm{Ca}-$ 2.5Ag alloy. The increase in $\mathrm{Q}^{-1}$ may be due the motion of substitutional $\mathrm{Ag}$ atoms in $\mathrm{Pb}$ lattice which have higher mobility due to their smaller size.

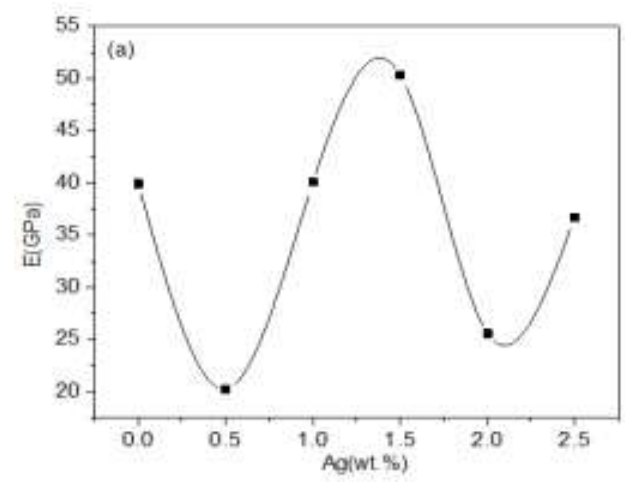

(a)

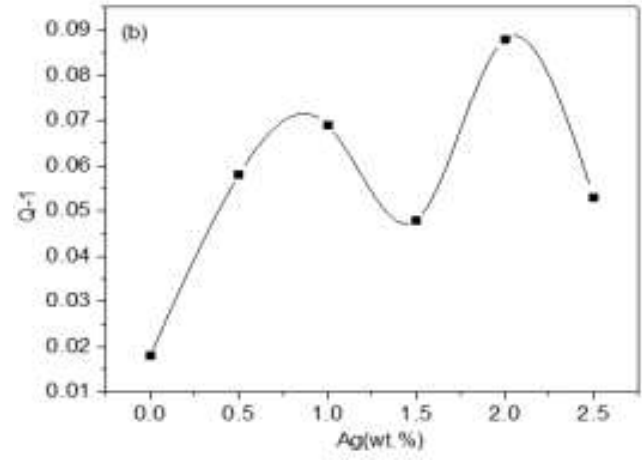

(b)

Figure 5. Variation of (a) Young's Modulus and (b) internal friction with Ca concentration for as-quenched melt-spun Pb-10Sn-2.5Ca-xAg ( $\mathrm{x}=0$, 0.5, 1, 1.5, 2, 2.5 wt.\%) alloys.

\subsubsection{MICROHARDNESS}

Figure 6. shows the variation of $\mathrm{HV}$ with $\mathrm{Ag}$ concentration of as-quenched melt -spun $\mathrm{Pb}$ 10Sn-2.5Ca-xAg ( $\mathrm{x}=0,0.5,1,1.5,2,2.5)$ alloys. HV was found to be $137.69 \mathrm{MPa}$ for $\mathrm{Pb}-$ 10Sn-2.5Ca alloy. HV decreased by addition of $\mathrm{Ag}$, which was found to be $71.05 \mathrm{MPa}$ for $0.5 \mathrm{wt} . \% \mathrm{Ag}$. HV was found to be $69.09 \mathrm{MPa}$ for $1 \mathrm{wt} . \% \mathrm{Ag}$ addition and for $1.5 \mathrm{wt} . \% \mathrm{Ag}, \mathrm{HV}$ increased to $126.91 \mathrm{MPa}$. Then $\mathrm{HV}$ decreased to $86.73 \mathrm{MPa}$ at 2 wt. $\% \mathrm{Ag}$ and $74.48 \mathrm{MPa}$ at $2.5 \mathrm{wt} . \% \mathrm{Ag}$. The decrease of $\mathrm{HV}$ may be due to that the solute of $\mathrm{Ag}$ atoms in $\mathrm{Pb}$ lattice causes local elastic strain which enhance dislocation mobility. The increase of HV may be due to the dispersion of $\mathrm{CaPb}_{3}$ and $\mathrm{Ag}_{3} \mathrm{Sn}$ intermetallic compounds, which are hard phases, in the alloy matrix. 


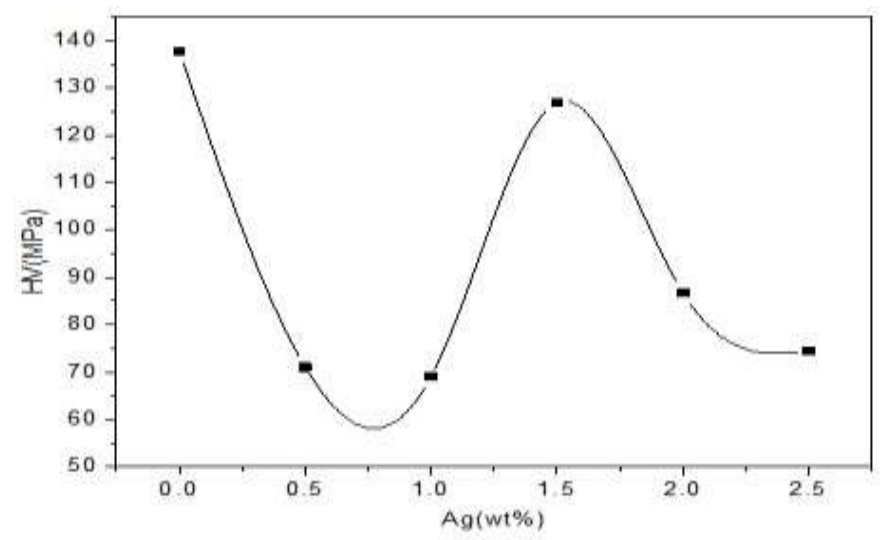

Figure 6. The variation of $\mathrm{HV}$ with $\mathrm{Ca}$ concentration of as-quenched melt -spun $\mathrm{Pb}-10 \mathrm{Sn}$ 2.5Ca-xAg (x=0, 0.5, 1, 1.5, 2, 2.5 wt.\%) alloys.

\subsubsection{MICROCREEP}

Figure 7. (a) shows the variation of HV with indentation time in time interval from 5 to $99 \mathrm{~s}$. It is obvious that $\mathrm{HV}$, for all alloys, decreases by increasing dwell time. Using indentation creep method, we can determine the microcreep behavior. By plotting the strain with indentation time in time interval from 5 to $99 \mathrm{~s}$ we obtain Figure 7. (b) which shows the microcreep behavior for as-quenched melt-spun Pb-10Sn-2.5Ca-xAg ( $\mathrm{x}=0,0.5,1,1.5,2,2.5$ wt.\%) alloys. The high creep resistance of these alloys is attributed to the dispersion of $\mathrm{CaPb}_{3}$ and $\mathrm{Ag}_{3} \mathrm{Sn}$ intermetallic compounds in the $\mathrm{Pb}$ matrix.

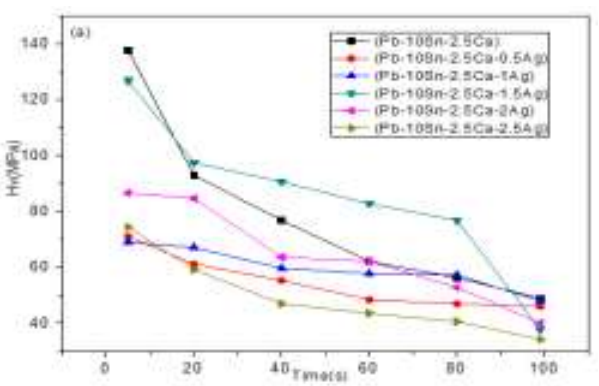

(a)

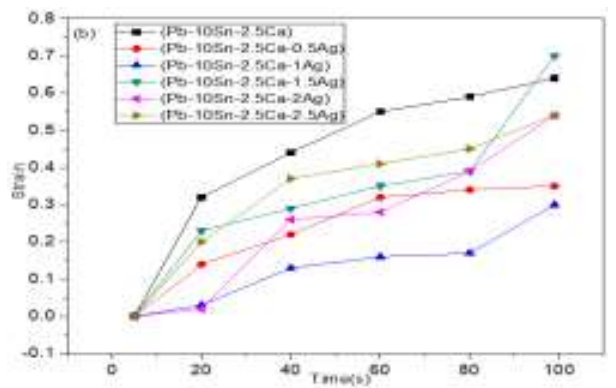

(b)

Figure 7. The variation of (a)Vickers microhardness number (HV) and (b) strain with dwell time for as-quenched melt-spun Pb-10Sn-2.5Ca-xAg ( $\mathrm{x}=0,0.5,1,1.5,2,2.5$ wt.\%)

\subsection{ELECTRICAL RESISTIVITY}

The measured electrical resistivity of as-quenched melt -spun Pb-10Sn-2.5Ca-xAg ( $\mathrm{x}=0,0.5$, $1,1.5,2,2.5$ wt. \%) alloys, at room temperature, is shown in Table 3. The average dimensions of sample were as the following; length $=4.5 \mathrm{~cm}$, width $=0.3 \mathrm{~cm}$ and thickness $=$ $45 \mu \mathrm{m})$. The electrical resistivity of $\mathrm{Pb}-10 \mathrm{Sn}-2.5 \mathrm{Ca}$ alloy was decreased with increasing $\mathrm{Ag}$ content this may be attributed to the increase of the number of free electrons due to the addition of $\mathrm{Ag}$. 
Table 3. Electrical resistivity variation with $\mathrm{Ca}$ concentration of as-quenched melt -spun Pb-10Sn-2.5Ca-xAg (x=0, 0.5, 1, 1.5, 2, 2.5 wt.\%) alloys

\begin{tabular}{|c|c|}
\hline Alloy & Electrical Resistivity at RT, $\rho \times 10^{-8} \Omega . m$ \\
\hline Pb-10Sn-2.5Ca & 29.25 \\
\hline Pb-10Sn-2.5Ca-0.5Ag & 30 \\
\hline Pb-10Sn-2.5Ca-1Ag & 24.9 \\
\hline Pb-10Sn-2.5Ca-1.5Ag & 16.8 \\
\hline Pb-10Sn-2.5Ca-2Ag & 21.4 \\
\hline Pb-10Sn-2.5Ca-2.5Ag & 28.9 \\
\hline
\end{tabular}

\subsection{ELECTROCHEMICAL BEHAVIOR}

Potentiodynamic polarization curves for Pb-10Sn-2.5Ca-xAg ( $\mathrm{x}=0,0.5,1,1.5,2,2.5$ wt.\%) alloys in $0.1 \mathrm{~N} \mathrm{H}_{2} \mathrm{SO}_{4}$ are shown in Figure 8. From these curves the corrosion potential $\mathrm{E}_{\text {Corr }}$ and corrosion current $\mathrm{I}_{\text {Corr }}$ were determined. Then the corrosion rate was calculated for all alloys as shown in Table 4. It is evident that the corrosion rate decreases by increasing Ag concentration to minimum value about $44.2 \mathrm{mpy}$ for $2.5 \mathrm{Ag}$ alloy. There are many factors affect corrosion such as the chemical composition and concentrations of the material under investigation and its environment, temperature, the crystal structure and microstructure of the material. All these factors were kept constant except the variation of $\mathrm{Ag}$ concentration. Therefore, $\mathrm{Ag}$ atoms may act as corrosion inhibitors in $\mathrm{Pb}-\mathrm{Sn}-2.5 \mathrm{Ca}$ alloy. This means that the addition of $\mathrm{Ag}$ atoms to enhances the corrosion resistance of $\mathrm{Pb}-10 \mathrm{Sn}-2.5 \mathrm{Ca}$ alloys.

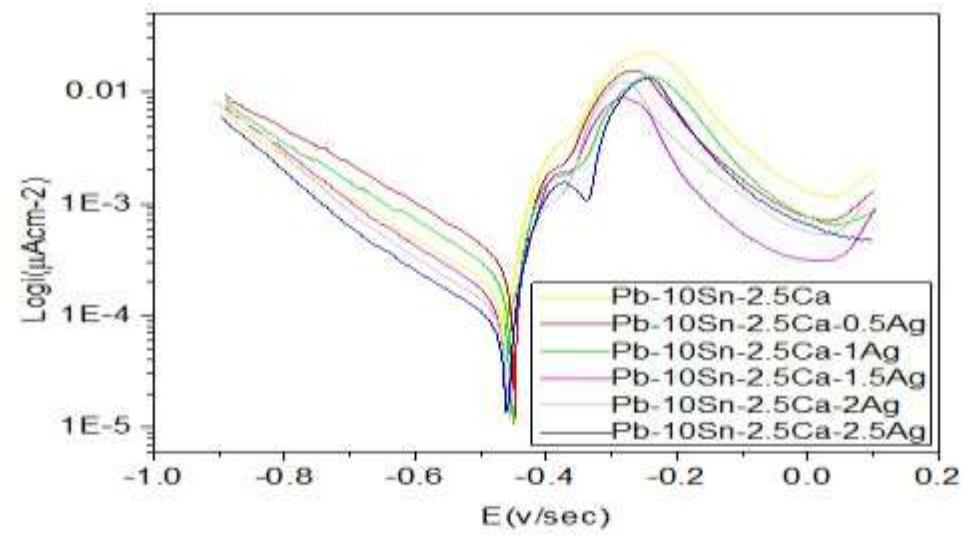

Figure 8. Potentiodynamic polarization curves for Pb-10Sn-2.5Ca-xAg ( $\mathrm{x}=0,0.5,1,1.5,2$, 2.5 wt. \%) alloys in $0.1 \mathrm{~N} \mathrm{H}_{2} \mathrm{SO}_{4}$ 
Table 4. corrosion potential $\mathrm{E}_{\mathrm{Corr}}$, corrosion current $\mathrm{I}_{\mathrm{Corr}}$ and corrosion rate of $\mathrm{Pb}-10 \mathrm{Sn}$ -

\begin{tabular}{|c|c|c|c|}
\hline Alloy & $\mathrm{I}_{\text {Corr }}\left(\mu \mathrm{A} \mathrm{cm}^{-2}\right)$ & $-\mathrm{E}_{\text {Corr }}(\mathrm{mV})$ & C. R (mpy) \\
\hline $\mathrm{Pb}-10 \mathrm{Sn}-2.5 \mathrm{Ca}$ & 224 & 462 & 95.98 \\
\hline $\mathrm{Pb}-10 \mathrm{Sn}-2.5 \mathrm{Ca}-0.5 \mathrm{Ag}$ & 369 & 448 & 158.4 \\
\hline $\mathrm{Pb}-10 \mathrm{Sn}-2.5 \mathrm{Ca}-1 \mathrm{Ag}$ & 256 & 454 & 110.68 \\
\hline $\mathrm{Pb}-10 \mathrm{Sn}-2.5 \mathrm{Ca}-1.5 \mathrm{Ag}$ & 142 & 458 & 60.97 \\
\hline $\mathrm{Pb}-10 \mathrm{Sn}-2.5 \mathrm{Ca}-2 \mathrm{Ag}$ & 131 & 458 & 56.31 \\
\hline $\mathrm{Pb}-10 \mathrm{Sn}-2.5 \mathrm{Ca}-2.5 \mathrm{Ag}$ & 103 & 459 & 44.20 \\
\hline
\end{tabular}

$2.5 \mathrm{Ca}-\mathrm{xAg}(\mathrm{x}=0,0.5,1,1.5,2,2.5 \mathrm{wt} . \%)$ alloys in $0.1 \mathrm{~N}_{2} \mathrm{SO}_{4}$

\section{CONCLUSION}

The obtained results show that the addition of $\mathrm{Ag}$ to $\mathrm{Pb}-10 \mathrm{Sn} 2.5 \mathrm{Ca}$ alloy improves the electrical properties as well as the associated mechanical properties. This is evident in the increase of Young's modulus, microcreep behavior and the enhancement of corrosion resistance. Therefore, the rapidly solidified melt-spun $\mathrm{Pb}-10 \mathrm{Sn}-2.5 \mathrm{Ca}-1.5 \mathrm{Ag}$ in wt.\% can be promising alloy as anode in electrowinning cell.

\section{REFERENCES}

[1] Tunnicliffe M, Mohammadi F, Alfantazi A. Polarization behavior of lead-silver anodes in zinc electrowinning. Journal of Electrochemical Society. 4 (2012) 159.

[2] Schlesingeer M E, King M J, Sole K C, et al. Extractive Metallurgy of Copper [M]. 5th E. The Netherlands, (2011) 360-369.

[3] J.A. Gonzalez, J. Rodrigues, and A. Siegmund, "Advances and Application of Lead Alloy Anodes for Zinc Electrowinning," (Tokyo: Mining and Materials Processing Institute of Japan 2 (2005) 1046.

[4] Jose Alberto Gonzalez, Jo Rodrigues, Andreas Siegmund, Anode paper ,2005.

[5] . R.D. Prengaman, "The Metallurgy and Performance of Cast and Rolled Lead Alloys for Battery Grids," Journal of Power Sources, 67 (1997) 267.

[6] A. Siegmund and R.D. Prengaman, "New Wrought Pb-Ag-Ca Anodes for Zinc Electrowinning to Produce a Protective Oxide Coating Rapidly," Lead-Zinc 2000, ed. J.E. Dutrizac et al. (2000) 589-597.

[7] W. Blum and G. Hogaboom, Principles of Electroplating and Electroforming (New York: McGrawHill Book Company, (1958) 343-344.

[8] Aaron Felder and R. David Prengaman, Lead Alloys for Permanent Anodes in the Nonferrous Metals Industry, (2006) 28-31.

[9] T. El-Ashram, R.M. Shalaby, J. Electron. Mater. 34 (2005) 212-215.

[10] Mustafa Kamal, Tarek El Ashram, Materials Science and Engineering A 456 (2007) 1-4.

[11] Calculated from ICSD using POWD-12++, 1997. 